\title{
The Protective Role of Atorvastatin against the Damage Induced by Cyclophosphamide on the Kidney and Testis of Adult Male Albino Rat: Histological, Biochemical and Histomorphmetric Study
}

\author{
HANAN N. GADALLAH, M.D. \\ The Department of Anatomy and Embryology, Faculty of Medicine, Cairo University
}

\begin{abstract}
Background: Cyclophosphamide (CP) is commonly used as chemotherapy for many cancers as well as autoimmune disorders. However, upon treatment, it was found that it had side effect which was the cause of histological and biochemical changes due to its oxidative stress capability. Atorvastatin (ATV) at a therapeutic low dose has been found to have antioxidant and anti-inflammatory properties.
\end{abstract}

Aim of Study: The present work was designed to evaluate the adverse effect of cyclophosphamide on the histology and oxidative markers of the kidneys and testes of adult male albino rats. Moreover, the study evaluated the role of Atorvastatin in prevention and treatment of the possible renal and testicular histological and biochemical alterations induced by cyclophosphamide.

Material and Methods: Twenty-four adult male albino rats were utilized in the present study, six in each group; Group I (control group), Group II receiving Cyclophosphmideonly, Group III receiving Atorvastatin 10 days afterCyclophosphmide, Group IV receiving Atorvastatin 5 days before and 5 days after Cyclophosphmide. The kidneys and testes of all rats were dissected and removed for investigation using light microscopic study, biochemical analysis, histomorphometrical and statistical study.

Results: Light microscopic examination of the renal cortex of the kidneys of group II showed shrunken renal glomeruli with subsequent widening of the Bowman's space, and interstitial inflammatory cellular infiltration. The proximal and distal convoluted tubules appeared dilated. Examination of the rat testes of group II displayed histological changes in theform of irregular distorted seminiferous tubules with marked degenerative changes of the spermatogenic epithelium. The interstitial spaces were wide containing pyknotic Leydig cells, dilated congested blood vessels and interstitial acidophilic exudate. The renal glomeruli and seminiferous tubules showed increased amount of collagen fibers deposition in the interstitial tissue in Masson's stained sections. Light microscopic examination of the kidneys and testes of group III and IV showed recovery of the histological changes.

Conclusion: Atorvastatin intake implicated outstanding structural recovery approaching the structural and biochemical

Correspondence to: Dr. Hanan N. Gadallah,

E-Mail: hanan.nabih2010@ gmail.com parameters of the control group, but the improvement in group IVwas much better than in group III.

Key Words: Cyclophosphamide - Kidney and testis - Atorvastatin.

\section{Introduction}

CYCLOPHOSPHAMIDE (CP), used in the treatment of many organ malignancies, and autoimmune disturbances byincreasing the number of the dendritic cells ortransportingthe hematopoietic stem cells from bone marrow to the lymph nodes thus activating the immune response [1-3]

Using CP was restricted in spite of its effectiveness because of its organ toxicity as a result ofthe generation of free radicals and oxidative stress [4]

Cyclophosphamide toxicity was explained as $\mathrm{CP}$ is inactive but its metabolites; phosphoramide mustardand acrolein, produced by the hepatic microsomal enzymes P450 system,bound with the alkylation nucleophilic sites in DNA. The resultingcross-linking nucleobases prevented DNA replication and protein synthesis [5].

Cyclophosphamide nephrotoxicity was very common because of high renal vascular perfusion and variation of solutes' concentration in urine. Glomerular and tubular affection, necrosis of the renal papillae, pyelonephritis and hemorrhagic cystitis were observed in rats after $\mathrm{CP}$ induction [4]. Secondary metastasis in the bladder and kidney was an adverse effect in cases with non-Hodgkin's lymphoma receiving CP therapy [6].

Cyclophosphamide resulted in toxicity in male reproductive system as it caused testicular injury manifested by severe permenant damage to the seminiferous tubulesdue to DNA damage that caused cell death [7-9]. 
The toxicity caused by CP active metabolitesaffected not only the tumor cells but also the healthy ones as CP caused degradation inlipids, proteins and DNA in different systems including the male reproductive system [10].

The adverse effects, caused by $\mathrm{CP}$ on the male reproductive system, were affected by many factors as CP dose, duration of its intake, and the relationship between the dose and the response to its intake $[11,12]$.

Literatures reported significant atrophy of many organsas testis, epididymis and seminal vesicles as a result of CP therapy and affecting their functions $[13,14]$

Other reviewers high lighted the toxic effect of $\mathrm{CP}$ regarding the laboratory findings that proved the decrease intestosterone serum levels due to degeneration of Leydig cells. Damage of Sertoli cells was also observed as a reduction in Lactate Dehydrogenase (LDH) levels causing germ cell death $[15,16]$.

CP therapy caused testicular atrophy manifested by arrested spermatogenesis with decrease in the diameter of seminiferous tubules and height ofits lining germinal epithelium. Sperm abnormalities showed a dramatic increase in their incidence with regression in the sperm count [4]. These findings were the result offree radical production and oxidative stress in the cellscausinga disproportion between antioxidants and pro-oxidants [17]

Low dose Atorvastatin (ATV) was known by its effectiveness in the treatment of hypercholesterolemia as well as its antioxidant and antiinflammatory actions [18]. The mechanism of synthetic potent statin in decreasing cholesterol synthesis in the liver was referred to its role ininhibiting the enzyme 3-Hydroxy 3-Methyl Glutaryl Coenzyme A (HMG-CoA) reductase and increasing the uptake of hepatic Low-Density Lipoprotein (LDL) by its receptors $[19,20]$.

ATV-at low dose-had therapeutic beneficial pleiotropic effects-having multiple effects from a single genefor being an antioxidant and used for inhibition of inflammatory responses [21,22]. On the other hand, high-dose of atorvastatin was found to cause many complications as nephrotoxicity and testicular injury [23].

So, the present work was designed to evaluate the role of Atorvastatin in prevention and treatment of the possible renal and testicular histological and biochemical alterations induced by cyclophosphamide.

\section{Material and Methods}

\section{Material:}

I- Chemicals:

1- Cyclophosphamide, was obtained from Baxter Oncology (Düsseldorf, Germany) as powder in $1 \mathrm{gm}$ vials. Rats were supplemented witha single dose of $200 \mathrm{mg} / \mathrm{kg}$, intraperitoneally [24]

2- Atorvastatin, was obtained from Pfizer Pharmaceutical Company in the form of atorvastatin calcium tablets (Lipitor). Rats were supplemented with oral daily dose of $10 \mathrm{mg} / \mathrm{kg}$ body weight for 10 days [20]

\section{II- Animals:}

The present study was carried out on twentyfour adult male albino rats weighing 250-350gm. Rats were housed in cages under standard laboratory and environmental conditions with free access to food and water.

\section{III- Experimental design:}

The rats were segregated into four groups (6 rats each);

Group I control group: Received standard diet only with no medications.

Group II, receiving Cyclophosphmide: Given intra-peritoneally in a single dose of $200 \mathrm{mg} / \mathrm{kg}$ body weight and left for 10 days.

Group III: Given intra-peritoneal injection of Cyclophosphamide in a single dose of $200 \mathrm{mg} / \mathrm{kg}$ body weight and received also Atorvastatin orally by gastric lavage in daily dose of $10 \mathrm{mg} / \mathrm{kg}$ body weight for 10 days.

Group IV: Received Atorvastatin orally by gastric lavage in daily dose of $10 \mathrm{mg} / \mathrm{kg}$ body weight for 5 days, then given intra-peritoneal injection of Cyclophosphamide in a single dose of $200 \mathrm{mg} / \mathrm{kg}$ body weight on the 6 th day, and finally given Atorvastatin orally by gastric lavage in daily dose of $10 \mathrm{mg} / \mathrm{kg}$ body weight for another 5 days.

By the end of the experimental period, the rats were sacrificed by decapitation ofkidneys and testeswere excised.

\section{Methods:}

Light microscopic studies: Kidneys and testeswere fixed in $10 \%$ formol saline, dehydrated in ethanol and embedded in paraffin. Paraffin sections were cut at $5 \mu \mathrm{m}$ thick mounted on slides and stained with;

1- Haematoxylin and eosin stain for general histology. 
2- Masson's trichrome stain for detection of collagen fibers deposition.

3- Periodic Acid-Schiff (PAS) stains for the optical density of the basement membrane and the glomerular capsule of the kidneys.

Biochemical analysis:

- Parts of the testes and kidneys obtained from each animal were prepared with $0.1 \mathrm{M}$ phosphate buffer saline solution and centrifuged at $1200 \mathrm{~g}$ for 10 minutes.

- The supernatant was used to determine the Malondialdehyde (MDA) and Glutathione (GSH) levels.

\section{Histomorphometric studies:}

The data were obtained using Leica Qwin 500 image analyzer computer coloured monitor, hard disc of IBM personal computer connected to the microscope and controlled by Leica Qwin 500 software.

\section{Using the measuring field menu,}

1- The mean diameter of the seminiferous tubules was measured in the Hx \& E-stained sections of the testes.

2- The height of the spermatogenic lining epithelium of the seminiferous tubules was measured in the $\mathrm{Hx} \&$ E-stained sections of the testes.

3- The mean area percent of collagen fibersin Masson's-stained sections of both kidney and testis specimens was measured.

4- The mean value of the optical densityof the basement membrane and the glomerular capsule using PAS-stained of the kidney specimens was measured.

\section{Statistical analysis:}

Values were presented as mean, Standard Deviation (SD) and confidence intervals values. Data were explored for normality using KolmogorovSmirnov test of normality. The results of Kolmogorov-Smirnov test indicated that data were normally distributed (parametric data), therefore, One way analysis of variance (ANOVA) was used to compare between groups.

The significance level was set at $p<0.05$. Statistical analysis was performed with SPSS 18.0 (Statistical Package for Scientific Studies, SPSS, Inc., Chicago, IL, USA) for Windows.

This study was conducted at the Department of Anatomy, Faculty of Medicine, Cairo University from March 2019-March 2020.

\section{Results}

Histological results:

Regarding the kidney:

Group I:

The cortex was seen with rounded glomeruli, each glomerulus was surrounded by a narrow capsular space lined by a single layer of flat squamous cells, parietal layer of Bowman's capsule Fig. (1A). The proximal convoluted tubules appeared with narrow lumen and were lined by few poorly demarcated cells with rounded vesicular basal nuclei. The distal convoluted tubules had wide lumen and were lined by numerous simple cuboidal cells with rounded nuclei Fig. (1B).

Using Masson's trichrome stain, the control kidneys were viewing thin parietal layer of Bowman's capsule as well as thin tubular basement membrane with minimal interstitial collagen tissue was visualized Fig. (4A).

PAS stain illustrated thin parietal layer of Bowman's capsule Fig. (5A), thin tubular basement membrane and intact brush border of the proximal convoluted tubules Fig. (5B).

\section{Group II:}

The rat kidney of this group revealed shrunken glomeruli with intra glomerular congestion and wide capsular space Fig. (2). The proximal and the distal convoluted tubules had wide lumen and their lining cells showed vacuolization with flattened pyknotic or fragmented nuclei. Some epithelial cells presented with exfoliation of their nuclei. Many inflammatory cellular infiltration and areas of hemorrhage surrounding the glomeruli were also observed Fig. (2).

Masson's trichrome stained sections showed focal areas of increased interstitial collagen fibrous tissue formation Fig. (4B).

Sections stained with PAS revealed thickened tubular basement membrane with loss of the luminal brush border of theproximal convoluted tubules in the majority of the examined specimens Fig. (6).

\section{Group III:}

In some rat kidney specimens, the glomeruli and the surrounded capsular spaces were widely separated with intra glomerular congestion. Moderate dilation of the proximal and distal convoluted tubules wasobserved Fig. (3A).

Masson's trichrome stained sections demonstrated increasein the interstitial collagen fibrous tissue in most of the experimental specimens Fig. (4C). 
In PAS stained section thickening of the parietal layer of Bowman's capsule as well as loss of the brush border of the proximal convoluted tubules Fig. (7).

\section{Group IV:}

Most of the glomeruli and the surrounded capsular space were apparently normal with intraglomerular congestion. Mild dilation of the proximal and distal convoluted tubules was seen Fig. (3B).

Masson's trichrome stained sections showedminimal collagen fibrous tissue formation Fig. (4D).

PAS-stained sections revealed identical histological architecture of the parietal layer of Bowman's capsule to the control group Fig. (8A). The basement membrane of most of the renal tubules was observed thin. Continuity of the apical brush border of the proximal convoluted tubules was obviously seen Figs. (8A,B).

\section{Regarding the testis:}

\section{Group I:}

The architecture of the seminiferous tubules were observed with regular basement membraneand lined with normal spermatogenic cells arranged in several layers. The spermatogenic epithelium consisted of spermatogonia which appeared as small cells with flat dark nuclei forming the basal layer, primary spermatocyte which was the largest spherical cell with large rounded nuclei, spermatid located often near the lumen with small pale nuclei and the sperms whichwere seen within the lumen of the tubule. The supporting Sertoli cells appeared as columnar cells resting on the basement membrane with ovoid nuclei. The interstitial cells of Leydig (L) were large polygonal cells with vesicular nuclei and acidophilic cytoplasm Fig. (9).

In sections stained with Masson's trichrome, minimal amount of collagen tissue deposited in between the seminiferous tubules was seen Fig. (13).

\section{Group II:}

The rat testes of this group illustrated irregular distorted seminiferous tubules with marked degeneration of the spermatogenic epithelium. The basement membrane of the tubules appeared irregular and separated from the lining spermatogenic epithelium with multiple vacuolations noticed in the basal compartment of the seminiferous tubules. The primary spermatocytes showed deeply stained pyknotic nuclei and fragmentation of nuclei (kary- orrhexis). The interstitial spaces showed massive acidophilic interstitial tissue exudate with degenerated Leydig cells Fig. (10).

Masson's trichrome-stained sections showed increased amount of collagen fibers deposited in the interstitial tissue and around dilated blood vessels Fig. (14).

\section{Group III:}

The majority of the testes of this group recorded nearly normal spermatogenic epithelial of the seminiferous tubules. Sporadic tubules were viewed with mild vacuolation and degenerative changes ask aryorrhexis and pyknosis of the 1ry spermatocytes. The luminawere frequently associated with residual bodies and spermatozoa. The interstitial tissue was demonstrated with nearly normal architecture. The Leydig cells showed few degenerated cells with deeply stained pyknotic nuclei Fig. (11).

Masson's trichrome-stained sections exhibited mild increase of collagen deposition in the interstitial tissue between the seminiferous tubules Fig.

\section{Group IV:}

The seminiferous tubules appeared nearly normal with their lining spermatogenic epithelium. Few 1ry spermatocytes were seen with mild degeneration ask aryorrhexis. The lumenof some seminiferous tubules was found to contain few residual bodies and spermatozoa. The interstitial tissue appeared identical to the control specimens with its Leydig cells Fig. (12).

Masson's trichrome-stained sections showed mild increase in collagen deposition in the interstitial tissue between these miniferous tubules Fig.

\section{Biochemical analysis:}

\section{- Biomarkers:}

\section{I- Malondialdehyde (MDA):}

In the Kidney, the highest mean value was recorded in group II, followed by group III, then group IV, with the least mean value recorded in group I. ANOVA test revealed that the difference between groups was statistically significant ( $p=$ 0.00). (Table 1), Bar Chart (1).

In the testis, the highest mean value was recorded in group II, followed by group III, then group $\mathrm{IV}$, with the least mean value recorded in group I. ANOVA test revealed that the difference between groups was statistically significant $(p=0.00)$. (Table 1), Bar Chart (1). 


\section{II- Glutathione (GSH):}

In the Kidney, the highest mean value was recorded in group I, followed by group IV and group III, with the least mean value recorded in group II. ANOVA test revealed that the difference between groups was statistically significant ( $p=$ 0.00). (Table 2), Bar Chart (2).

In the testis, the highest mean value was recorded in group I, followed by group III, then group IV, with the least mean value recorded in group II. ANOVA test revealed that the difference between groups was statistically significant $(p=0.00)$. (Table 2), Bar Chart (2).

\section{Results of histomorphometric study:}

\section{I- Collagen fibers mean area percent:}

In the testis, the highest mean value was recorded in group II, followed by group III, then group $\mathrm{IV}$, with the least mean value recorded in group I. ANOVA test revealed that the difference between groups was statistically significant $(p=0.00)$. (Table 3), Bar Chart (3).

In the kidney, the highest mean value was recorded in group II, followed by group III, then group IV, with the least mean value recorded in group I. ANOVA test revealed that the difference between groups was statistically significant ( $p=$ 0.00). (Table 3), Bar Chart (3).

2- Regarding height of seminiferous tubules, the highest mean value was recorded in group I, followed by group IV, then group III, with the least mean value recorded in group II. ANOVA test revealed that the difference between groups was statistically significant $(p=0.00)$. (Table 4$)$, Bar Chart (4)

3- Regarding diameter of Spermatogenic epithelium, the highest mean value was recorded in group I, followed by group IV, then group III, with the least mean value recorded in group II. ANOVA test revealed that the difference between groups was statistically significant $(p=0.00)$. (Table 4), Bar Chart (5).

\section{4- Glycogen optical density.}

In the kidney, the highest mean value was recorded in group I, followed by group IV, then group III, with the least mean value recorded in group II. ANOVA test revealed that the difference between groups was statistically significant ( $p=$ 0.00). (Table 5), Bar Chart (6).
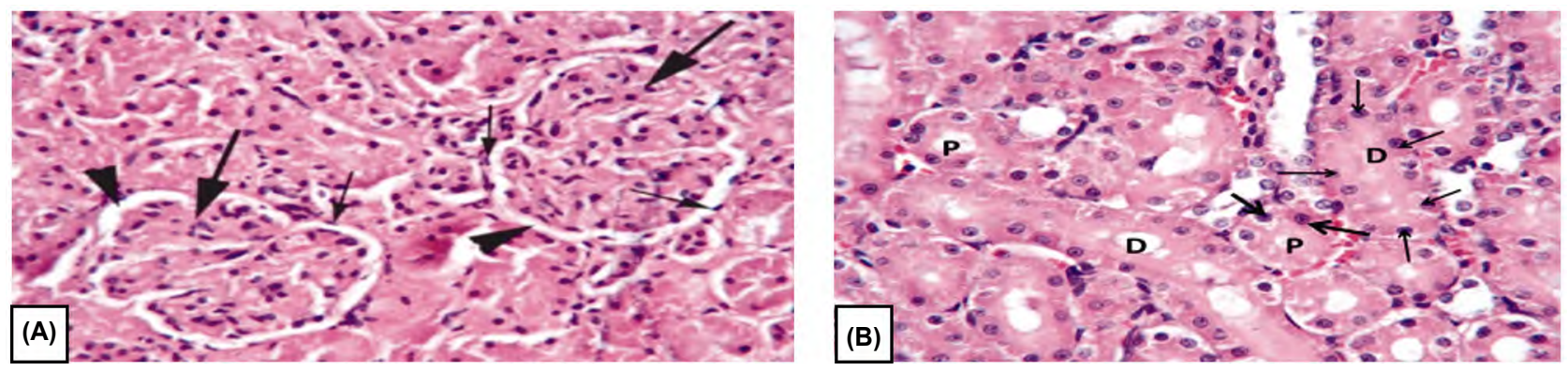

Fig. (1): (A,B): Micrograph of a rat kidney (control group), showing: A- Rounded glomeruli (thick arrows), each glomerulus was surrounded by a narrow capsular space (arrow heads) lined by flat squamous cells of parietal layer (thin arrows) of Bowman's capsule. B- The proximal convoluted tubules $(\mathrm{P})$ with narrow lumen and rounded vesicular nuclei near the base of the cell (thick arrows). The distal convoluted tubules (D) are with wide lumen and lined by simple cuboidal cells with rounded nuclei (thin arrows). A- (Hx. \& E. X200). B- (Hx. \& E. X400).
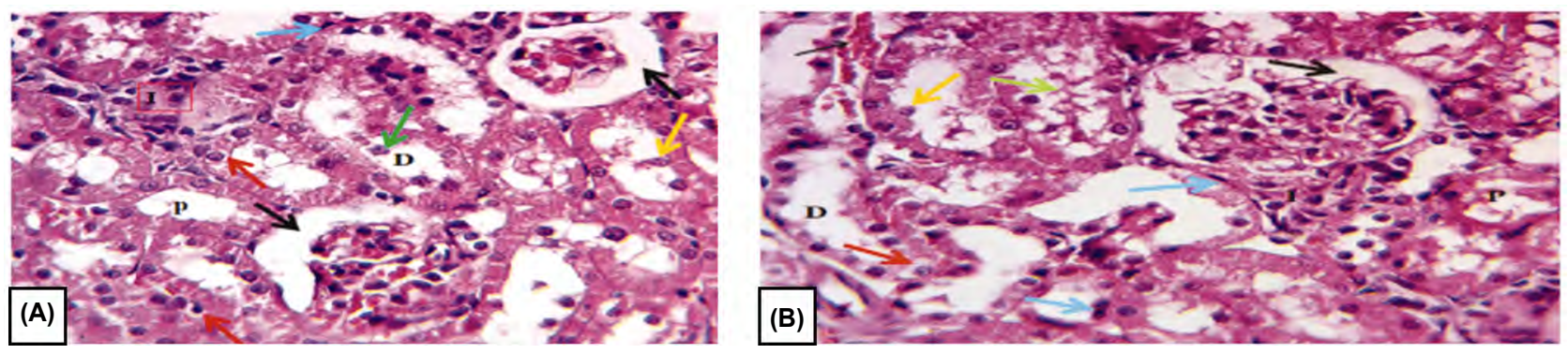

Fig. (2): Micrograph of a rat kidney (group II), displaying shrunken glomeruli with intra glomerular congestion and wide capsular space (black arrows). The proximal convoluted tubules (P) and the distal convoluted tubules (D) have wide lumen and their lining cells show vacuolization (red arrows) with flattened pyknotic (blue arrows) or fragmented nuclei (yellow arrows). Some tubular epithelial cells show exfoliation of their nuclei (green arrows). Many inflammatory cellular infiltration (I) surrounding the glomeruli are observed. Note areas of hemorrhage (thin arrow) in (2b). (Hx. \& E. X400). 

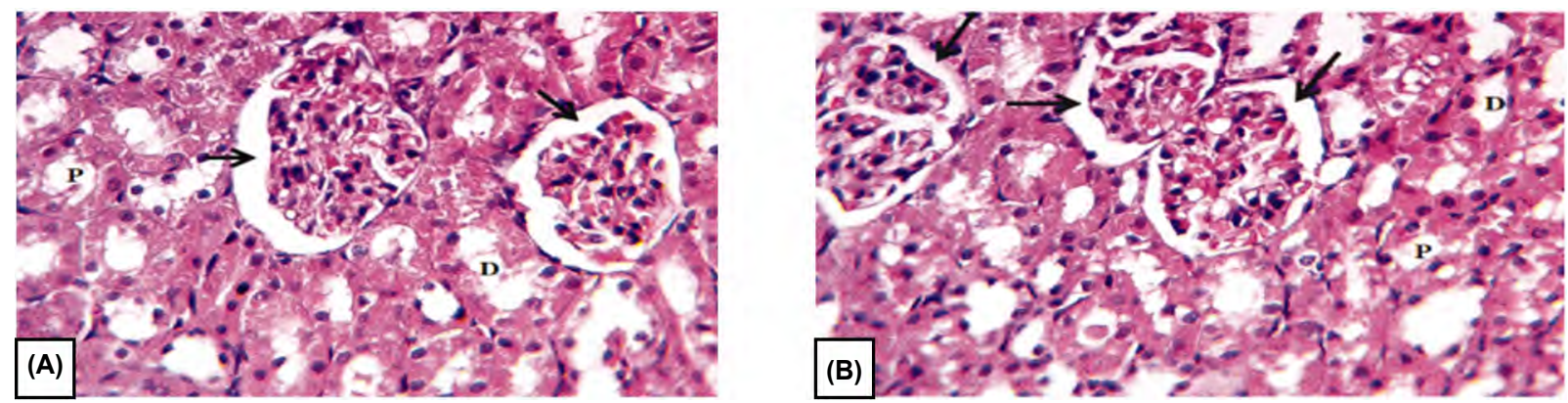

Fig. (3): Micrograph of rat kidneys, showingthe glomeruli and the surrounded capsular space widely separated with intra glomerular congestion (black arrows). Moderate in (3A) (Group III) to mild in (3B) (Group IV) dilation of the proximal (P) and distal (D) convoluted tubules are seen. (Hx. \& E. X400)

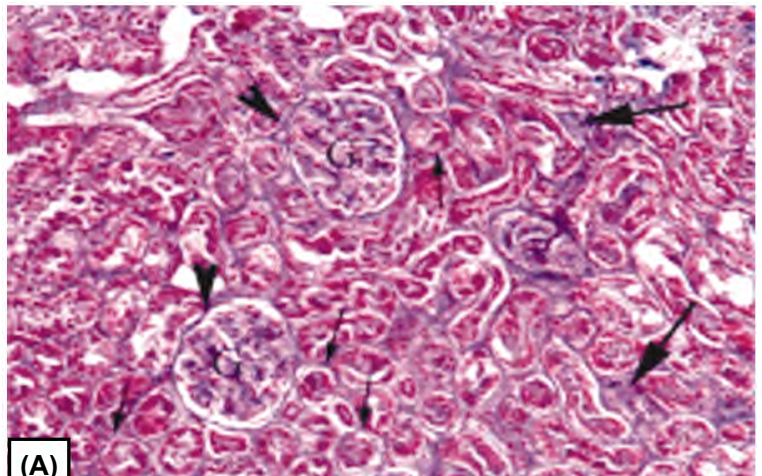

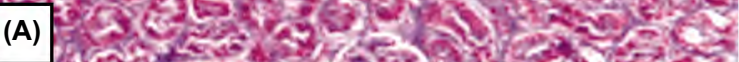

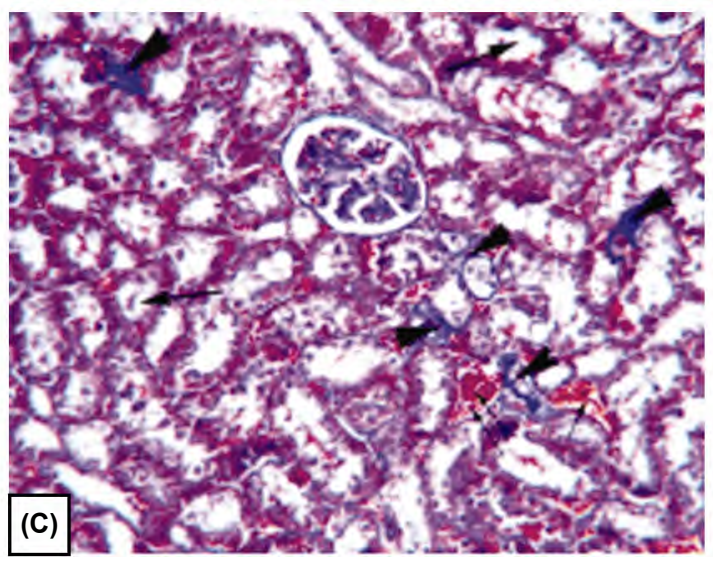

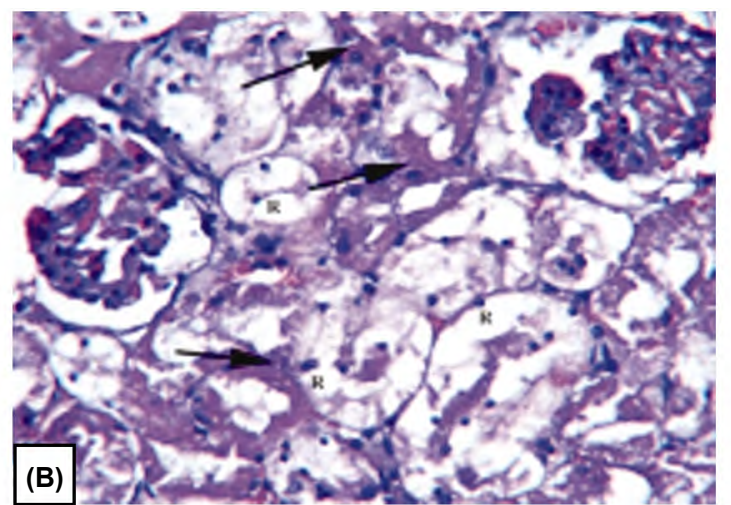

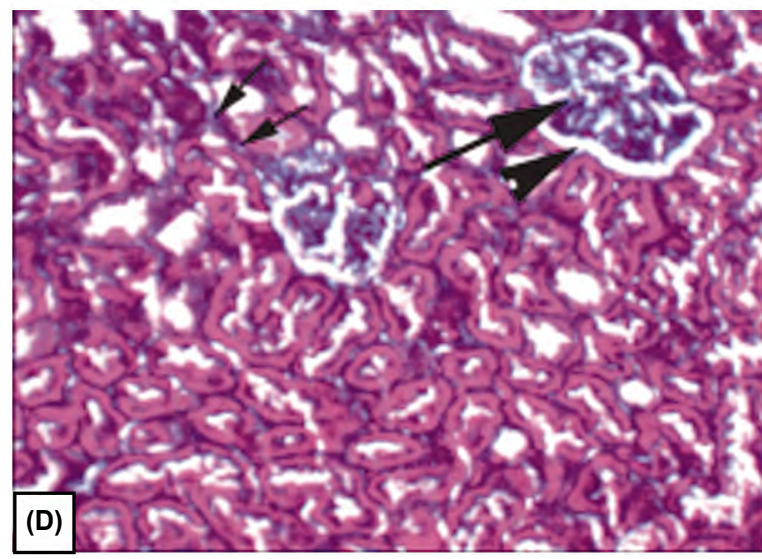

Fig. (4): (A, B, C, D): Micrograph of rat kidneys, illustrating: A- (Control group) thin parietal layer of Bowman's capsule (arrowheads) and thin tubular basement membrane (thin arrows). Minimal interstitial collagen tissue (thick arrows). B- (Group II), focal areas of increased interstitial collagen fibrous tissue content (arrows). C- (Group III), aggregate areas of collagen connective tissue (arrowheads) in the interstitium. D- (Group IV), limited collagen fibrous tissue in the interstitium (arrows). Note apparently normal glomerulus (long arrow) with nearly normal capsular space (arrowhead). (Masson's trichrome X200).

Fig. (5): (A,B): Micrograph of a rat kidney (control group), viewing: aThin parietal layer of Bowman's capsule (arrows) and B- Thin basement membrane (arrowheads) of both proximal (P) and distal (D) convoluted tubules, intact brush border (arrows) of the proximal convoluted tubules.
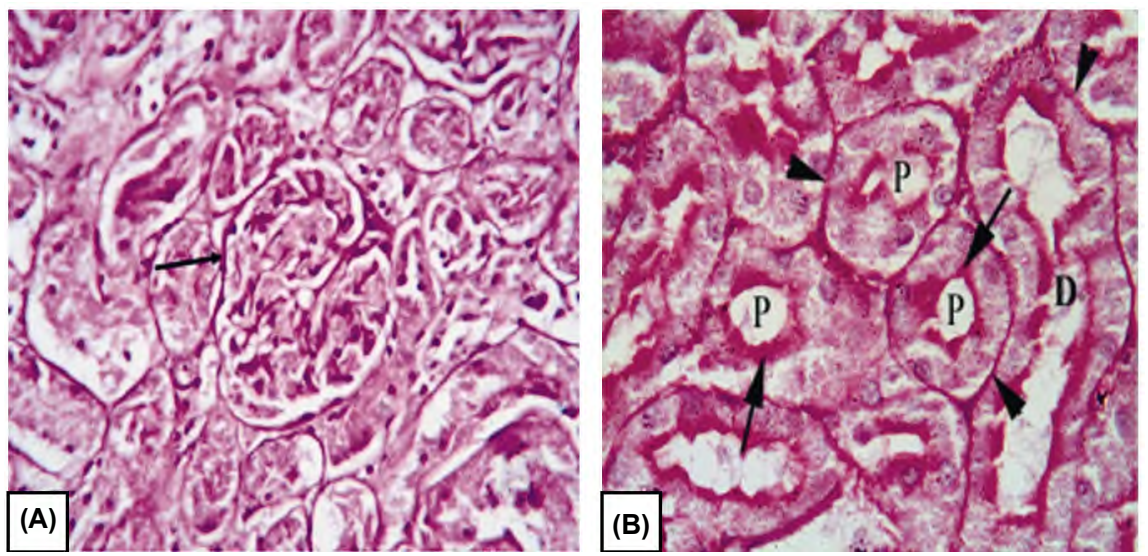
Fig. (6): Micro-graph of a rat kidney (Group II), illustrating distal (D) and proximal (P) tubules with thick tubular basement membrane (arrows). Loss of luminal brush border the proximal tubules is seen (arrow heads). (PAS X400).

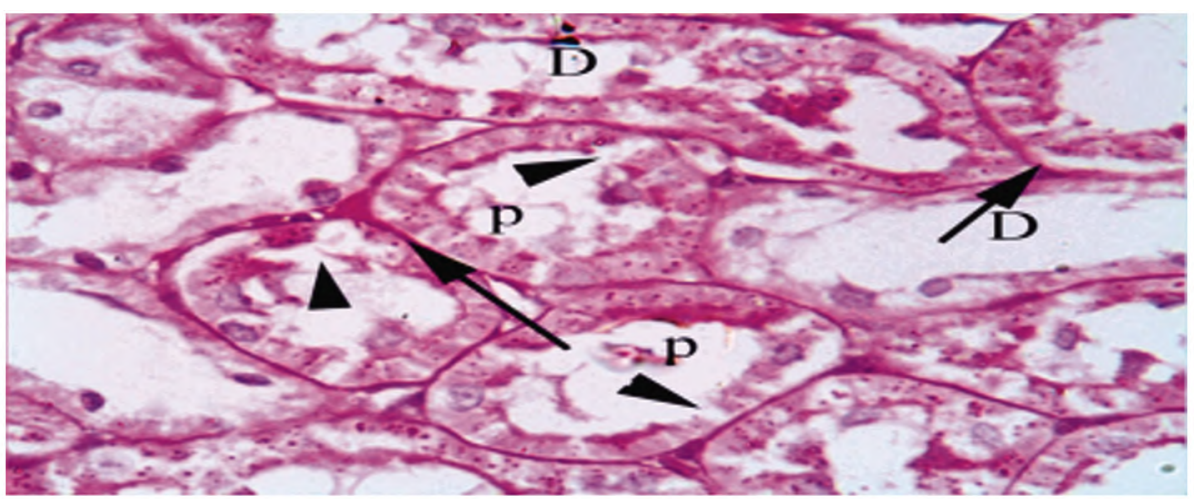

Fig. (7): Micrograph of a rat kidney (group III), viewing thick parietal layer of Bowman"s capsule (arrows) as well as loss of the brush border (arrowheads) of the proximal convoluted tubules (P).
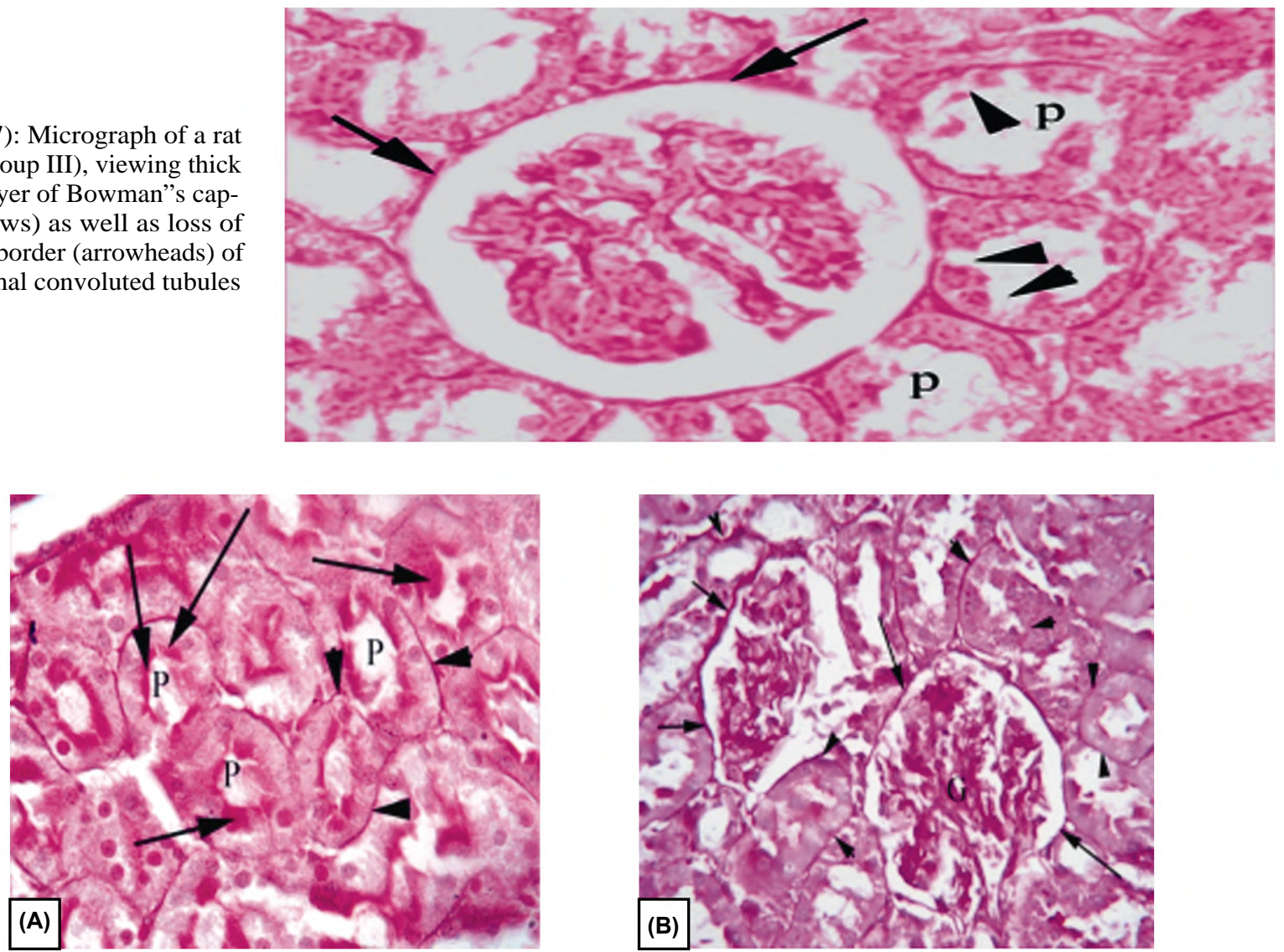

Fig. (8): (A,B): Micrograph of a rat kidney (group IV), exhibiting: A- Thin tubular basement membrane (arrowheads) The proximal convoluted tubules (P) with intact brush border (arrows). B- Glomeruli (G) with normal thickness of the parietal layer of Bowman's capsule (arrows) as well as the tubular basement membrane (arrowheads). (PAS X400).

Fig. (9): Micrograph of a rat testis (control group), showing the seminiferous tubules are lined with normal spermatogenic cells arranged in several layers consisting ofspermatogonia $(\mathrm{Sg})$, primary spermatocyte $(\mathrm{S} 1)$, spermatid (S2) and the sperms (Z). Note Sertoli cells $(\mathrm{Sc})$ resting on the basement membrane and the interstitial cells of Leydig (L). (Hx. \& E. X400).

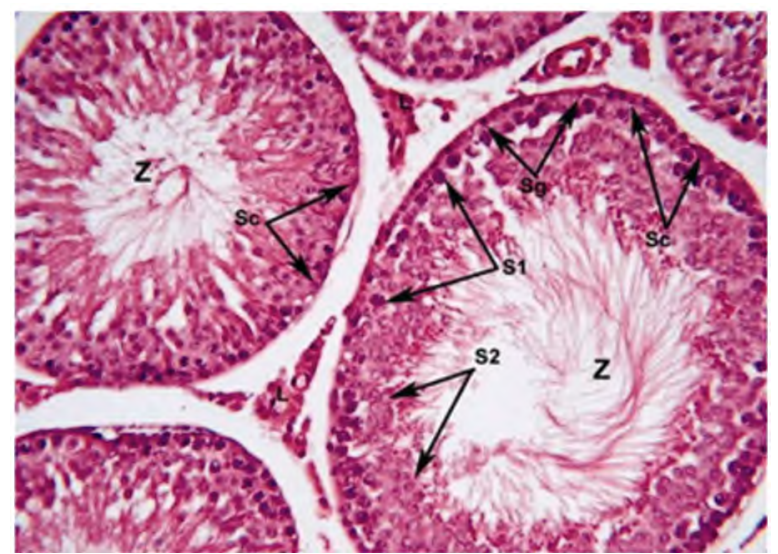


Fig. (10): (A,B,C): Micrograph of a rat testis (group II), showing irregular distorted seminiferous tubules with marked degeneration of the spermatogenic epithelium (ST). The basement membrane of the tubules appeared irregular (blue arrows) and separated from the lining spermatogenic epithelium. Multiple spaces of vacuolations $(\mathrm{V})$ were seen in the basal compartment of the tubules. The 1ry spermatocytes showed deeply stained pyknotic nuclei (red arrows) and karyorrhexis appear as fragmented nuclei (arrowheads) as in (10B). The interstitial tissue showed massive acidophilic interstitial tissue exudate with degenerated Leydig cells (L) as in (10C). (Hx. \& E. X400).
Fig. (11): (A,B): Micrograph of a rat testis (group III), illustrating nearly normal spermatogenic epithelial of the seminiferous tubules with mild vacuolation (V) and degeneration as karyorrhexis (black arrows) and pyknosis of the 1ry spermatocytes (red arrows). The lumen contains few residual bodies and spermatozoa. The interstitial tissue appears nearly normal with its Leydig cells show few degenerated cells with deeply stained pyknotic nuclei (green arrow). (Hx. \& E. X400).

Fig. (12): (A,B): Micrograph of a rat testis (group IV), displaying nearly normal seminiferous tubules with spermatogenic epithelial exhibiting mild degeneration as karyorrhexis of the 1ry spermatocytes (arrows). The lumen contains few residual bodies (RB) and spermatozoa $(Z)$. The interstitial tissue appears identical to the controlwith its Leydig cells (L). (Hx. \& E. X400).
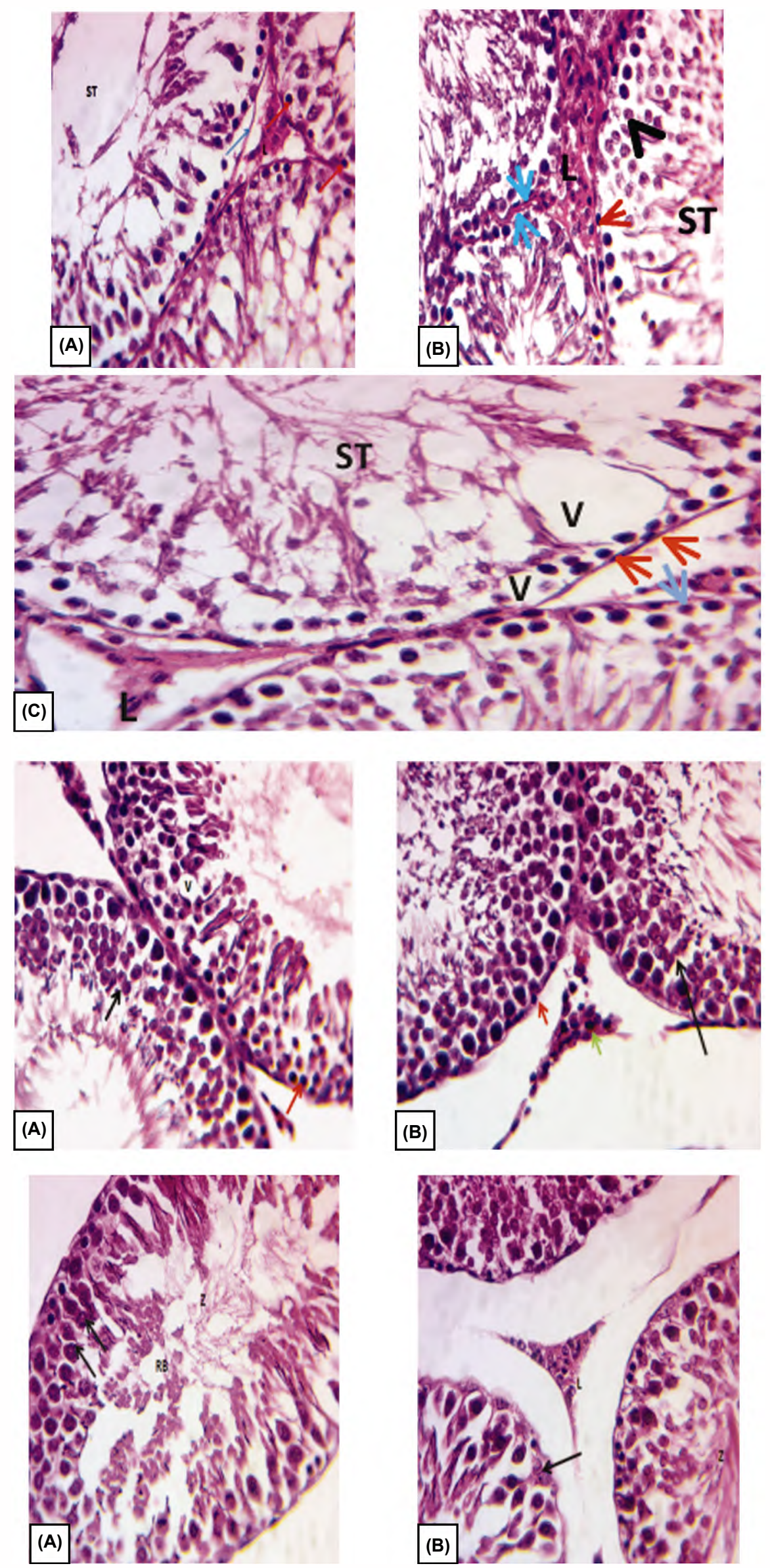
Fig. (13): Micrograph of a rat testis (control group), showing thin layer of collagenous fibers in between the tubules (arrows). (Masson's trichrome X 200).

Fig. (14): (A \& B): Micrograph of a rat testis (group II), showing increased amount of collagen fibre deposition in between the tubules in the interstitial tissue (blue arrows) and around dilated blood vessels (black arrows). (Masson's trichrome X200).

Fig. (15): (A \& B): Micrograph of a rat testis of group III (A) and group IV (B), showing mild increase in the collagen deposition in the interstitial tissue between the tubules (arrows). (Masson's trichrome X200).
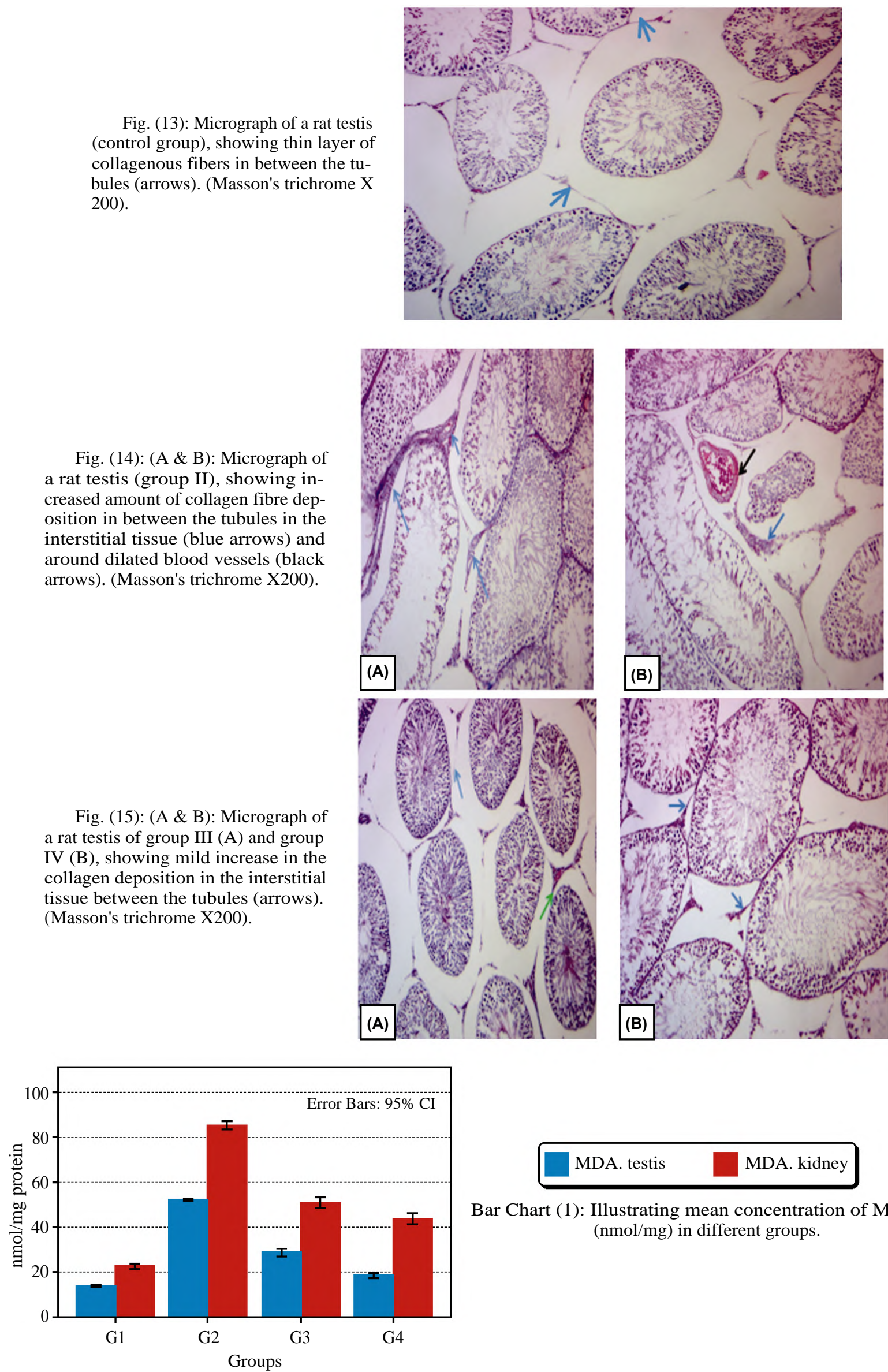

MDA. testis

MDA. kidney

Bar Chart (1): Illustrating mean concentration of MDA $(\mathrm{nmol} / \mathrm{mg})$ in different groups. 
Table (1): Descriptive statistics and comparison of MDA concentration ( $\mathrm{nmol} / \mathrm{mg}$ ) in different groups (ANOVA test).

\begin{tabular}{|c|c|c|c|c|c|c|c|c|c|}
\hline & \multirow{2}{*}{ Mean } & \multirow{2}{*}{$\begin{array}{l}\text { Std. } \\
\text { Dev }\end{array}$} & \multirow{2}{*}{$\begin{array}{l}\text { Std. } \\
\text { Error }\end{array}$} & \multicolumn{2}{|c|}{$\begin{array}{l}95 \% \text { confidence } \\
\text { interval for mean }\end{array}$} & \multirow{2}{*}{ Min } & \multirow{2}{*}{$\operatorname{Max}$} & \multirow{2}{*}{$\mathrm{F}$} & \multirow{2}{*}{$p$} \\
\hline & & & & Lower Bound & Upper Bound & & & & \\
\hline \multicolumn{10}{|l|}{ Testis: } \\
\hline G1 & $13.70 d$ & .26 & .08 & 13.52 & 13.88 & 13.20 & 14.20 & 1272.03 & $.000 *$ \\
\hline G2 & $52.07 \mathbf{a}$ & .23 & .07 & 51.91 & 52.23 & 51.70 & 52.50 & & \\
\hline G3 & $28.71^{b}$ & 2.40 & .76 & 26.99 & 30.43 & 24.30 & 32.60 & & \\
\hline G4 & $18.40 \mathrm{c}$ & 1.82 & .58 & 17.10 & 19.70 & 15.40 & 21.40 & & \\
\hline \multicolumn{10}{|c|}{ Kidney: } \\
\hline G1 & $22.50 \mathrm{~d}$ & 1.71 & .54 & 21.28 & 23.72 & 20.00 & 25.00 & 886.94 & $.000 *$ \\
\hline G2 & $85.21^{\mathbf{a}}$ & 2.61 & .83 & 83.34 & 87.08 & 80.10 & 90.10 & & \\
\hline G3 & $50.60 \mathrm{~b}$ & 3.19 & 1.01 & 48.32 & 52.88 & 45.80 & 57.00 & & \\
\hline G4 & $43.56 \mathrm{c}$ & 3.28 & 1.04 & 41.22 & 45.90 & 37.60 & 49.60 & & \\
\hline
\end{tabular}

Significance level $p<0.05$, *: Significant.

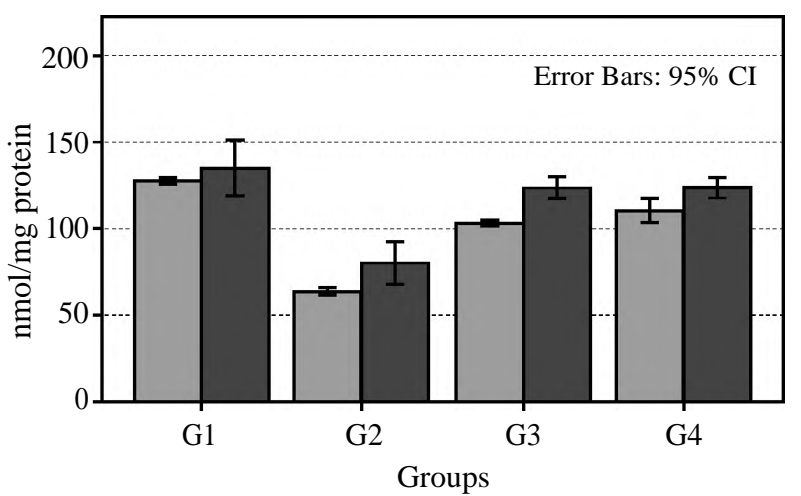

GSH. testis

GSH. kidney

Bar Chart (2): Illustrating mean concentration of GSH $(\mathrm{nmol} / \mathrm{mg})$ in different groups.

Table (2): Descriptive statistics and comparison of GSH concentration ( $\mathrm{mmol} / \mathrm{mg}$ ) in different groups (ANOVA test).

\begin{tabular}{|c|c|c|c|c|c|c|c|c|c|}
\hline & \multirow{2}{*}{ Mean } & \multirow{2}{*}{$\begin{array}{l}\text { Std. } \\
\text { Dev }\end{array}$} & \multirow{2}{*}{$\begin{array}{l}\text { Std. } \\
\text { Error }\end{array}$} & \multicolumn{2}{|c|}{$\begin{array}{l}95 \% \text { confidence } \\
\text { interval for mean }\end{array}$} & \multirow{2}{*}{ Min } & \multirow{2}{*}{ Max } & \multirow{2}{*}{$\mathrm{F}$} & \multirow{2}{*}{$p$} \\
\hline & & & & Lower Bound & Upper Bound & & & & \\
\hline \multicolumn{10}{|l|}{ Testis: } \\
\hline G1 & $127.20 \mathbf{a}$ & 2.74 & .87 & 125.24 & 126.16 & 123.10 & 131.30 & 27.097 & $.000 *$ \\
\hline $\mathrm{G} 2$ & $63.50 c$ & 2.74 & .87 & 61.54 & 65.46 & 59.30 & 67.70 & & \\
\hline $\mathrm{G} 3$ & $102.80 \mathbf{b}$ & 2.59 & .82 & 100.95 & 104.65 & 97.70 & 105.90 & & \\
\hline G4 & $100.16 \mathbf{b}$ & 31.57 & 9.98 & 77.57 & 122.75 & 11.40 & 120.40 & & \\
\hline \multicolumn{10}{|l|}{ Kidney: } \\
\hline G1 & $134.49 \mathbf{a}$ & 22.66 & 7.16 & 118.28 & 150.70 & 72.50 & 152.30 & 22.89 & $.000 *$ \\
\hline $\mathrm{G} 2$ & $79.94 \mathbf{b}$ & 16.91 & 5.35 & 67.85 & 92.03 & 65.50 & 119.30 & & \\
\hline G3 & $123.22 \mathbf{a}$ & 8.48 & 2.68 & 117.15 & 129.29 & 109.20 & 139.00 & & \\
\hline G4 & $123.58 \mathbf{a}$ & 5.88 & 2.40 & 117.41 & 129.76 & 113.40 & 130.70 & & \\
\hline
\end{tabular}

Significance level $p<0.05$, *: Significant.

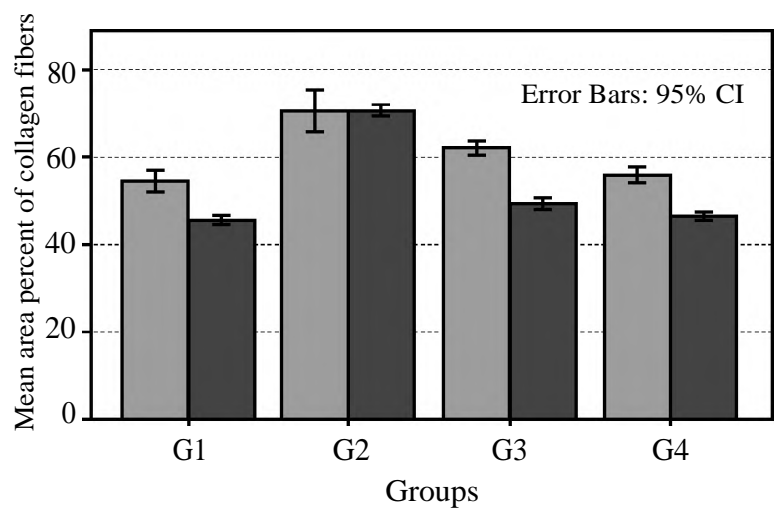

Collagen. testis

Collagen. kidney

Bar Chart (3): Illustrating mean area percent of collagen fibers in testis and kidney in different groups. 
Table (3): Descriptive statistics and comparison of area percent in different groups (ANOVA test).

\begin{tabular}{|c|c|c|c|c|c|c|c|c|c|}
\hline & \multirow{2}{*}{ Mean } & \multirow{2}{*}{$\begin{array}{l}\text { Std. } \\
\text { Dev }\end{array}$} & \multirow{2}{*}{$\begin{array}{l}\text { Std. } \\
\text { Error }\end{array}$} & \multicolumn{2}{|c|}{$95 \%$ confidence interval for mean } & \multirow{2}{*}{ Min } & \multirow{2}{*}{ Max } & \multirow{2}{*}{$\mathrm{F}$} & \multirow{2}{*}{$p$} \\
\hline & & & & Lower Bound & Upper Bound & & & & \\
\hline \multicolumn{10}{|l|}{ Testis: } \\
\hline G1 & $54.50^{\mathrm{c}}$ & 3.53 & 1.12 & 51.97 & 57.02 & 51.36 & 63.45 & 31.693 & $.000 *$ \\
\hline G2 & $70.47 \mathbf{b}$ & 6.57 & 2.08 & 65.77 & 75.17 & 63.57 & 86.39 & & \\
\hline G3 & $61.96 \mathbf{a}$ & 2.33 & .74 & 60.30 & 63.62 & 57.70 & 65.34 & & \\
\hline G4 & $55.85^{\mathrm{c}}$ & 2.41 & .76 & 54.13 & 57.58 & 53.17 & 60.54 & & \\
\hline \multicolumn{10}{|c|}{ Kidney: } \\
\hline G1 & $45.40^{\mathrm{c}}$ & 1.39 & .44 & 44.41 & 46.40 & 43.17 & 47.40 & 533.386 & $.000^{*}$ \\
\hline G2 & $70.52 \mathbf{a}$ & 1.86 & .59 & 69.19 & 71.85 & 66.61 & 72.55 & & \\
\hline G3 & $49.25 \mathbf{b}$ & 1.86 & .59 & 47.92 & 50.58 & 46.33 & 52.20 & & \\
\hline G4 & $46.47^{c}$ & 1.30 & .41 & 45.54 & 47.39 & 44.43 & 48.30 & & \\
\hline
\end{tabular}

Significance level $p<0.05$, *: Significant.

Table (4): Descriptive statistics and comparison of histomorphometric results in different groups (ANOVA test).

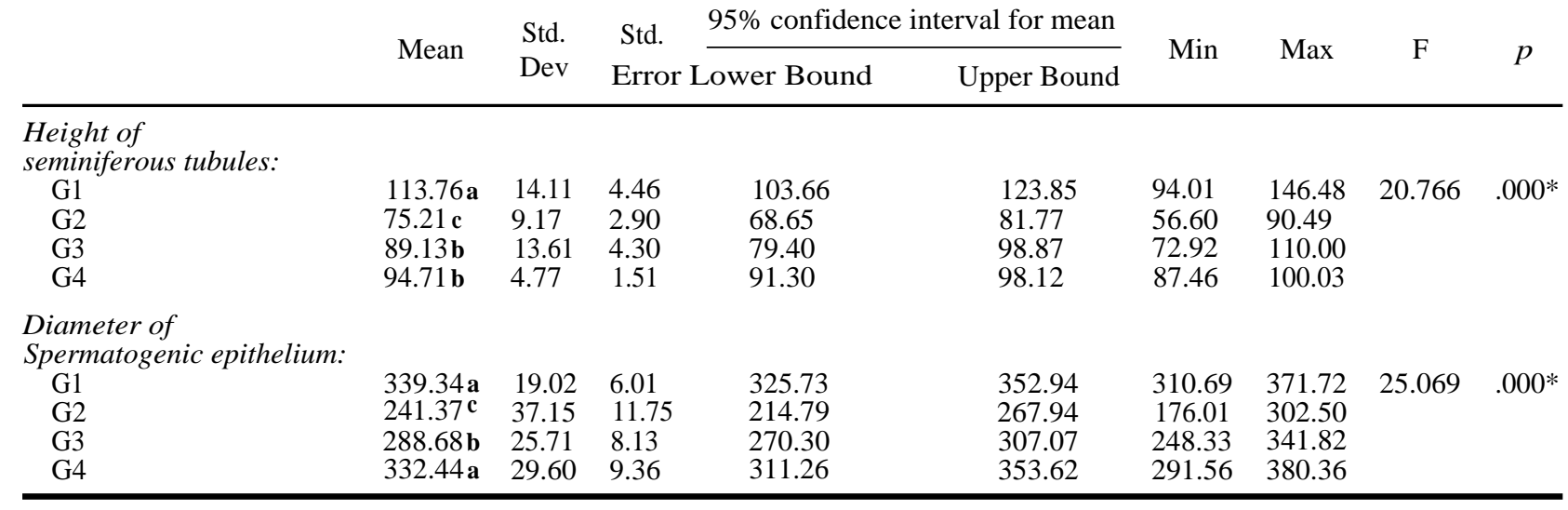

Significance level $p<0.05, *$ : Significant.

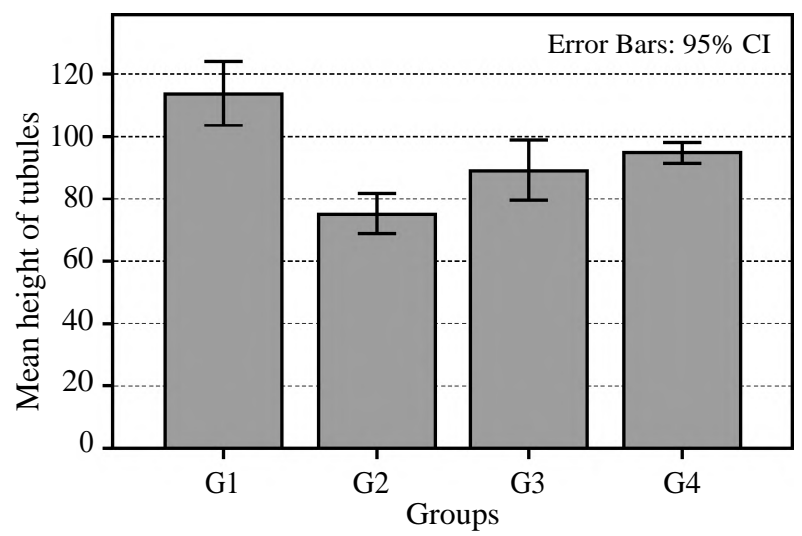

Bar Chart (4): Illustrating mean height of seminiferous tubules in different groups.

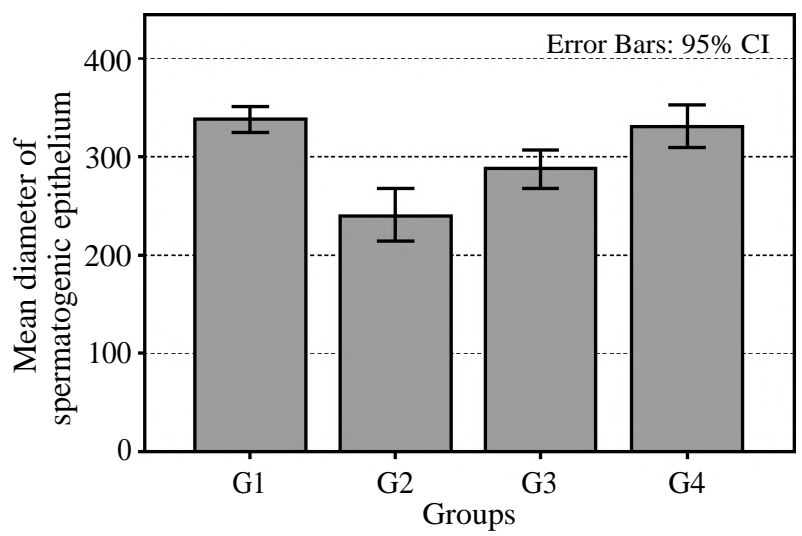

Bar Chart (5): Illustrating mean diameter of spermatogenic epithelium in different groups.

Table (5): Descriptive statistics and comparison of PAS optical density in kidney different groups (ANOVA test).

\begin{tabular}{|c|c|c|c|c|c|c|c|c|c|}
\hline \multirow{2}{*}{ Kidney } & \multirow{2}{*}{ Mean } & \multirow{2}{*}{$\begin{array}{l}\text { Std. } \\
\text { Dev }\end{array}$} & \multirow{2}{*}{$\begin{array}{l}\text { Std. } \\
\text { Error }\end{array}$} & \multicolumn{2}{|c|}{$95 \%$ confidence interval for mean } & \multirow{2}{*}{ Min } & \multirow{2}{*}{$\operatorname{Max}$} & \multirow{2}{*}{$\mathrm{F}$} & \multirow{2}{*}{$p$} \\
\hline & & & & Lower Bound & Upper Bound & & & & \\
\hline$\overline{\mathrm{G} 1}$ & $56.48 \mathrm{a}$ & 2.19 & .89 & 54.19 & 58.78 & 52.90 & 59.12 & 156.616 & $.000 *$ \\
\hline G2 & $25.63^{d}$ & 2.05 & .84 & 23.48 & 27.78 & 22.75 & 27.90 & & \\
\hline G3 & $34.17 \mathrm{c}$ & 3.07 & 1.25 & 30.95 & 37.39 & 30.36 & 38.62 & & \\
\hline G4 & $44.44 b$ & 2.96 & 1.21 & 41.34 & 47.55 & 40.42 & 48.55 & & \\
\hline
\end{tabular}

Significance level $p<0.05$, *: Significant. 


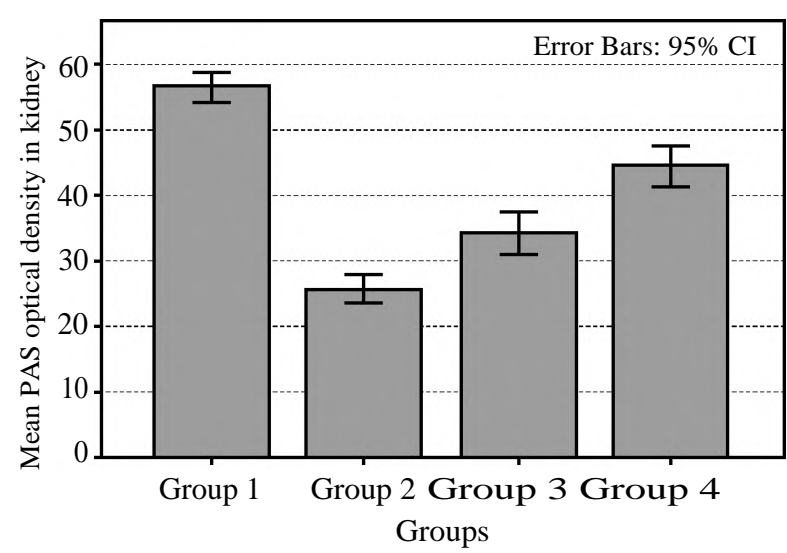

Bar Chart (6): Illustrating mean PAS optical density in Kidney in different groups.

\section{Discussion}

Cyclophosphamide (CP) was an effective cytotoxic alkylating agent [5] . CP itself was inactive but metabolized by the hepatic microsomal cytochrome $\mathrm{P} 450$, producing the active alkylating metabolites; aldophosphamide-mustard and acrolein. These metabolites were the cause of CP toxicityby inducing oxidative stress and production of free radicals and Reactive Oxygen Species (ROS). These metabolites also reacted with the essential cell macromolecules as proteins, membrane lipids and DNA causing structural and functional changes [25]

$\mathrm{CP}$ nephrotoxicity was very common because most of CP metabolites were excreted through the urine $[4,26]$. On the other hand, researchers reported that CP did not show any adverse effect on the kidney as its metabolite, acrolein was not nephrotoxic [27].

The present work revealed shrunken renal glomeruli with subsequent widening of the Bowman's space which could be explained bythe oxidative stress that was indicated by the oxidative markers in the kidney tissues [28,29]. Moreover, literatures added that the kidney was very sensitive to many xenobiotics toxicants, as it had high vascular perfusion and variation of solutes' concentration in urine. Another added that the cause wasarteriolopathy of the afferent arteriole of the glomeruli with secondary glomerular ischemia [30] .

In the present study, kidney examination of rats treated with $\mathrm{CP}$ revealed dilatation of the renal tubules and this was attributed to the fact that the tubules especially the proximal ones were metabolically active and very susceptible to hypoxia. Another explaination was that $\mathrm{CP}$ caused damage of DNA due to interaction of acrolein with DNA [31].
The tubular nephrotoxic changes encountered in the current work included cytoplasmic vacuolization and loss of the apical brush border of the proximal convoluted tubules. Those findings were explained by the uptake of macromolecules into the proximal tubular cells resulted in an increased osmotic gradient across the plasma membrane; water transported into the cells which became swollen and vacuolated [32]. CP toxicity caused degenerative changes in the epithelial lining of the tubules as apoptosis as $\mathrm{CP}$ induced oxidative stress by forming crosslinks in DNA-DNA and DNAprotein and thus caused DNA damage [20].

Inflammatory cellular infiltration was detected in the current study as the resulting ischemia led to the production of inflammatory mediators causing an interstitial inflammatory infiltration [33].

Glomerular congestion was noted as the endothelial dysfunction caused by oxidative stress and nitric oxide production led to vascular damage [34].

However, interstitial fibrosis was observed in the examined kidney specimens of group II which could be due to the increased production of both angiotensin II inducing fibroblast activation and transforming growth factors that had fibrotic properties thus increasing deposition and decreasing degradation of collagen fibers [35]. The increase in the interstitial fibrous tissue was supported by the histomorphometric results which depicted a statistically highly significant increase in the mean area percent of collagen fibers in CP-treated rats compared to the control group.

The present work also revealed histological changes in the testes induced by $\mathrm{CP}$ as irregular distorted seminiferous tubules with marked degeneration of the spermatogenic epithelium. These findings could be related to DNA damage or chromosomal aberration in the somatic and germ cells caused by CP affecting their morphology [36-38] Furthermore, other authors explained that $\mathrm{CP}$, as an alkylating agent, was the main cause of spermatogenesis dysfunction as it induced apoptosis due to high levels of ROS and oxidative stress $[39,40]$.

The current study was detected the presence of residual bodies in the lumen of the seminiferous tubules. This was attributed to the degeneration of the cellular components or the presence of latestage spermatids in the atrophic tubules indicating spermatid retention and phagocytosis by the Sertoli cells [41]. 
From the findings of the present work, interstitial spaces were wide and containing pyknotic Leydig cells, dilated blood vessels and interstitial acidophilic exudate. The wideness of the interstitial spaces was attributed to the degeneration of the spermatogenic epithelium and tubular atrophy. However, the interstitial acidophilic exudate in between the seminiferous tubules could be explained by the dilatation and congestion of the interstitial blood vessels caused by the direct toxic effect of chemotherapy on the blood vessel walls $[36,41]$

The mean glutathione (GSH) was significantly decreased in group II as compared to the control group. It was significantly increased in groups III and IV. The mean malondialdehyde (MDA) was significantly increased in group II as compared to the control group. It was significantly decreasedingroups III and IV.

Decreased antioxidant enzyme GSH and increased MDA level could be related to $\mathrm{CP}$ induced oxidative stress. MDA, the most frequently used biomarker of lipid peroxidation, was the main indicator of oxidative damage initiated by ROS that led to altered membrane structure and enzyme inactivation [42]

Cyclophosphamide had a pro-oxidant nature, resulting in the decrease in the activities of the antioxidant enzymes and increase in lipid peroxidation in a variety of organs in mice and rats [43] GSH acted either as a non-enzymatic antioxidant by direct interaction of-SH group with Reactive Oxygen Species (ROS) or shared in the enzymatic detoxification reaction for ROS, as a cofactor or coenzyme. The depletion of GSH content led to direct conjugation of $\mathrm{CP}$ and its metabolites with free or protein bound-SH groups inducing renal damage [20]

Cyclophosphamide,through exerting oxidative damage and lipid peroxidation, played an important role in the toxicity of many xenobiotics. The antioxidants as Superoxide Dismutase (SOD) increased in cells in response to the oxidative stress as a protective mechanism to eliminate xenobiotics. So, antioxidant system might be an adaptation to the oxidative stress and this explained the capacity of the testis antioxidant system to protect against oxidative damage caused by $\mathrm{CP}$ [44]

Low dose Atorvastatin (ATV), the most common synthetic statins, not only reduced the level of plasma lipoproteins and cholesterol by inhibiting enzyme 3-hydroxy-3-methylglutaryl coenzyme A (HMG-CoA) reductase but also, acted as antioxi- dant and anti-inflammatory drug [18,19]. Thus, ATV protected cell structure against oxidative stress and inhibits the reduction of endogenous antioxidant enzymes [20].

Furthermore, authors found that intake of ATV, as an antioxidant, 5 days before and 5 days after administration of $\mathrm{CP}$ reduced apoptosis in the cells $[45,46]$

The exact mechanism of ATV in the treatment of oxidative stress is not fully detected. However, it could be explained as ATV decreased the lipid peroxidation thus removing the activity of the free radicalsas supported by decreased DNA damage and cellular damage [47]. ATV also inhibited lipid independent isoprenoidsthus improving the oxidative stress and inflammation [48]

The effect of ATV was suggested to be dose dependent. High dose ATV caused many complications as hepatotoxicity, nephrotoxicity and testicular injury by induction of oxidative stressand lipid peroxidation [49]. On the other hand, low dose ATV reduced hepatotoxicity by eliminating oxidative stresswithout affecting fertility and reproduction [50]

From the present work, it is recommended the use ofCyclophosphamide with low dose Atorvastatin.

\section{References}

1- HAUBITZ M., KANNO T., LUCIMARA S., et al.: Acute and Long-term Toxicity of Cyclophosphamide. Tx. Med., 19: 26-31, 2007.

2- MONTGOMERY M. and COTTER-FOX M.: Mobilization and collection of autologous hematopoietic progenitor/stem cells. Clinical Advances in Hematology and Oncology, 5 (2): 127-36, 2007.

3- SALEM M., DIAZ-MONTERO C., AL-KHAMI A., et al.: Recovery from cyclophosphamide-induced lymphopenia results in expansion of immature dendritic cells which can mediate enhanced prime-boost vaccination antitumor responses in vivo when stimulated with the TLR3 agonist poly (I:C). The Journal of Immunology, 182 (4): 2030-40, 2009.

4- LIM S., HYUN S., LEE S., et al.: Potential urinary biomarkers of nephrotoxicity in cyclophosphamide-treated rats investigated by NMR-based metabolic profiling. Journal of biochemical and molecular toxicology, 31 (3): e21871, 2017.

5- McDONALD G., SLATTERY J., BOUVIER M., et al. Cyclophoshamide metabolism, liver toxicity, and mortality following hematopoietic stem cell transplantation. Blood, 101 (5): 2043-8, 2003.

6- TRIPATHI D. and JENA G.: Astaxanthin inhibits cytotoxic and genotoxic effects of cyclophosphamide in mice germ cells. Toxicology, 248 (2-3): 96-103, 2008. 
7- HOWELL S. and SHALET S.: Testicular function following chemotherapy. Hum. Reprod Update, 7: 363-9, 2001.

8- SELVAKUMAR E., PRAHALATHAN C., MYTHILI Y., et al.: Protective effect of dL- p-lipoic acid in cyclophosphamide induced oxidative injury in rat testis. ReprodToxicol, 19: 163-7, 2004.

9- SELVAKUMAR E., PRAHALATHAN C., SUDHARSAN P., et al.: Protective effect of lipoic acid on cyclophosphamide-induced testicular toxicity. Clin. Chim. Acta, 367: 114-9, 2006.

10- SINGH S., LATA S. and TIWARI K.: Antioxidant potential of Phyllanthusfraternus Webster on cyclophosphamide induced changes in sperm characteristics and testicular oxidative damage in mice. Indian J. Exp. Biol., 53 (10): 647-56, 2015.

11- KANNO T., LUCIMARA A., NATÁLIA A., et al.: Toxic effects of different doses of cyclophosphamide on the reproductive parameters of male mice, Brazilian Journal of Pharmaceutical Sciences, 45 (2), 2009.

12- DRUMOND A., WENG C., WANG G., et al.: Effects of multiple doses of cyclophosphamide on mouse testes: Accessing the germ cells lost, and the functional damage of stem cells. Reprod Toxicol, 32 (4): 395-406, 2011.

13- DAS B., MALLICK M., DEBNATH M., et al.: Protective effect of ascorbic acid on cyclophosphamide-induced testicular gametogenic and androgenic disorders in male rats. Asian journal of andrology, 4 (3): 201-8, 2002.

14- JALALI A., HASANZADEH S. and MALEKINEJAD H.: Achilleamillefolium inflorescence aqueous extract ameliorates cyclophosphamide-induced toxicity in rat testis. Stereological evidences. Chin. J. Nat. Med., 10 (4): 247-54, 2012

15- AHMED A., EL-MARAGHY A. and RIZK M.: Role of the KATP channel in the protective effect of nicorandil on cyclophosphamide-induced lung and testicular toxicity in rats. Scientific reports, 5: 14043, 2015.

16- LI J., HU Y., ZHANG Q., et al.: Strontium fructose 1, 6diphosphate alleviate cyclophosphamide-induced oligozoospermia by improving antioxidant and inhibiting testicular apoptosis via FAS/FASL pathway. Andrologia, 47 (9): 995-1003, 2015.

17- SHARMA S., SHARMA P., KULURKAR P., et al.: Iridoid glycosides fraction from Picrorhizakurroa attenuates cyclophosphamide-induced renal toxicity and peripheral neuropathy via PPAR-y mediated inhibition of inflammation and apoptosis. Phytomedicine, 36: 108-17, 2017.

18- ZHOU Q. and LIAO J.: Pleiotropic effects of statins, Basic research and clinical perspectives. Circ. J., 74 (5): 818-26, 2010.

19- SCHROTT H., KNAPP H., DAVILA M., et al.: Effect of atorvastatin on blood lipid levels in the first 2 weeks of treatment: A randomized, placebo-controlled study. Am. Heart J., 140 (2): 249-52, 2000.

20- HAMZEH M., HOSSEINIMEHR J., KHALATBARY R., et al.: Atorvastatin mitigates cyclophosphamide-induced hepatotoxicity via suppression of oxidative stress and apoptosis in rat model. Research in pharmaceutical sciences, 13 (5): 440, 2018.

21- FASSETT R. and COOMBES J.: Statins in acute kidney injury: Friend or foe? BMJ, 346: f1531, 2013.
22- CREVAR-SAKAC M., VUJIC' Z., KOTUR-STEVULJEVIC' J., et al.: Effects of atorvastatin and artichoke leaf tincture on oxidative stress in hypercholesterolemic rats. Vojnosanit. Pregl., 73: 178-87, 2016.

23- HASHEM R., RASHD L., HASHEM K., et al.: Cerium oxide nanoparticles alleviate oxidative stress and decreases Nrf-2/HO-1 in D-GALN/LPS induced hepatotoxicity. Biomed Pharmacother., 73: 80-6, 2015.

24- CHAKRABORTY M., BHATTACHARJEE A. and KAMATH V.: Cardioprotective effect of curcumin and piperine combination against cyclophosphamide-induced cardiotoxicity. Indian journal of pharmacology, 49 (1): 65, 2017.

25- KHORWAL G., CHAUHAN R. and NAGAR M.: Effect of cyclophosphamide on liver in albino rats: A comparative dose dependent histomorphological study. International Journal of Biomedical and Advance Research, 8 (3): 102 $107,2017$.

26- MURALI V. and KUTTAN G.: CurculigoorchioidesGaertn Effectively Ameliorates the Uro-and Nephrotoxicities Induced by Cyclophosphamide Administration in Experimental Animals. Integr. Cancer Ther., 15 (2): 205-15, 2016.

27- HAENEN G., VERMEULEN N., TSOI J., et al.: Activation of the microsomal glutathione-S-transferase and reduction of the glutathione dependent protection against lipid peroxidation by acrolein. Biochem. Pharmacol., 37: 1933, 1988.

28- SAKR S. and EL-MESSADY F.: Cyclophosphamide Induced Histologial and Immunohistochemical Alterations in Kidney of Albino Rats: The Ameliorative Effect of Fennel Oil. International Journal of Sciences, 6 (08): 7887, 2017.

29- EL-NAGGAR S., ALM-ELDEEN A., GERMOUSH M., et al.: Ameliorative effect of propolis against cyclophosphamide-induced toxicity in mice. Pharmaceutical biology, 53 (2): 235-41, 2015.

30- REHMAN M., TAHIR M., ALI F., et al.: Cyclophosphamide-induced nephrotoxicity, genotoxicity, and damage in kidney genomic DNA of Swiss albino mice: The protective effect of Ellagic acid. Molecular and Cellular Biochemistry, 365 (1-2): 119-27, 2012.

31- HAAS M., SONNENDAY J., CICONE S., et al.: Isometric tubular vacuolization in renal allograft biopsy specimens of patients receiving low-dose intravenous immunoglobulin for a positive cross match. Transplantation, 78: 549$56,2004$.

32- FERNANDO A., RAJH., OUHTIT A., et al.: In vivo evidence of hepato- and reno-protective effect of garlic oil against sodium nitrite-induced oxidative stress. International Journal of Biological Sciences, 5 (3): 249-55, 2010.

33- BUFFOLI B., PECHÁNOVÁ O., KOJSOVÁ S., et al.: Provinol prevents CsA-induced nephro-toxicity by reducing reactive oxygen species, iNOS, and F-kB expression. Journal of Histochemistry and Cytochemistry, 53 (12): 1459-68, 2005.

34- BOBADILLA A. and GAMBA G.: New insights into the pathophysiology of cyclosporine nephrotoxicity: A role of aldosterone. American Journal of Physiology. Renal Physiology, 293: F2-F9, 2007. 
35- YUAN D., WANG H., HE H., et al.: Protective effects of total flavonoids from Epimedium on the male mouse reproductive system against cyclophosphamide induced oxidative injury by up-regulating the expressions of SOD3 and GPX1. Phytother. Res., 28 (1): 88-97, 2014.

36- HAMZEH M., HOSSEINIMEHR J., KARIMPOUR A., et al.: Cerium oxide nanoparticles protect cyclophosphamide-induced testicular toxicity in mice. International journal of preventive medicine, 10, 2019.

37- CODRINGTON A., HALES B. and ROBAIRE B.: Spermiogenic germ cell phase-speci•c DNA damage following cyclophosphamide exposure. J. Androl., 25 (3): 354-62, 2004

38- SUJAYRAJ S., NAIK P. and VISHMA L.: Cyclophosphamide Induced Testicular Toxicity-A Comparison Between Acute and Subchronic Doses. Medical Science, 5 (4), 2016.

39- ASIRI Y.: Probucol attenuates cyclophosphamide induced oxidative apoptosis, p53 and Bax signal expression in rat cardiac tissues. Oxid Med. Cell Longev., 3 (5): 308-16, 2010.

40- NARAYANA K., VERGHESE S. and JACOB S.: LAscorbic acid partially protects two cycles of cisplatin chemotherapy-induced testis damage and oligoasthenoteratospermia in a mouse model. Experimental and Toxicologic Pathology Journal, 6: 553-63, 2009.

41- AFKHAMI-ARDAKANI M., HASANZADEH S., et al.: Antioxidant effects of Spirulinaplatensis (Arthrospiraplatensis) on cyclophosphamide-induced testicular injury in rats. In Veterinary Research Forum, 9 (1): 35, 2018.

42- HAQUE R., BIN-HAFEEZ B., PARVEZ S., et al.: Aqueous extract of walnut (Juglansregia L.) protects mice against cyclophosphamide-induced biochemical toxicity. Human \& experimental toxicology, 22 (9): 473-80, 2003.

43- TURK G., ÇERIBASI A., SAKIN F., et al.: Antiperoxi- dative and anti-apoptotic effects of lycopene and ellagic acid on cyclophosphamide-induced testicular lipid peroxidation and apoptosis. Reprod. Fertil. Dev., 22: 587-96, 2010.

44- GONZÁLEZ-FLORES D., De NICOLA M., BRUNI E., et al.: Nanoceria protects from alterations in oxidative metabolism and calcium overloads induced by TNF a and cycloheximide in U937 cells: Pharmacological potential of nanoparticles. Mol. Cell Biochem., 397 (1-2): 245 53, 2014.

45- BAO X., WU C. and LU G.: Atorvastatin inhibits homocysteine-induced oxidative stress and apoptosis in endothelial progenitor cells involving Nox4 and p38MAPK. Atherosclerosis, 210 (1): 114-21, 2010.

46- NAEIMI R., TALEBPOUR F., KHALATBARY A., et al.: Atorvastatin mitigates testicular injuries induced by ionizing radiation in mice. Reprod. Toxicol., 72: 115-21, 2017.

47- RAMANJANEYULU S., TRIVEDI P., KUSHWAHA S., et al.: Protective role of atorvastatin against doxorubicininduced cardiotoxicity and testicular toxicity in mice. J. Physiol. Biochem., 69 (3): 513-25, 2013.

48- FURUYA T., POLETTO C., FAVARO R., et al.: Antiinflammatory effect of atorvastatin ameliorates insulin resistance in monosodium glutamate-treated obese mice. Metabolism, 59 (3): 395-9, 2010.

49- NASRI H., HASANPOUR Z., NEMATBAKHSH M., et al.: The effect of the various doses of atorvastatin on renal tubular cells; an experimental study. J. Nephropathol., 5: 111-5, 2016

50- FARAG M., MOHAMED M. and YOUSSEF E.: Assessment of Hepatic Function, Oxidant/Antioxidant Status, and Histopathological Changes in Rats Treated With Atorvastatin: Effect of Dose and Acute Intoxication With Acetaminophen. Hum. Exp. Toxicol., 34 (8): 828-37, 2015. 


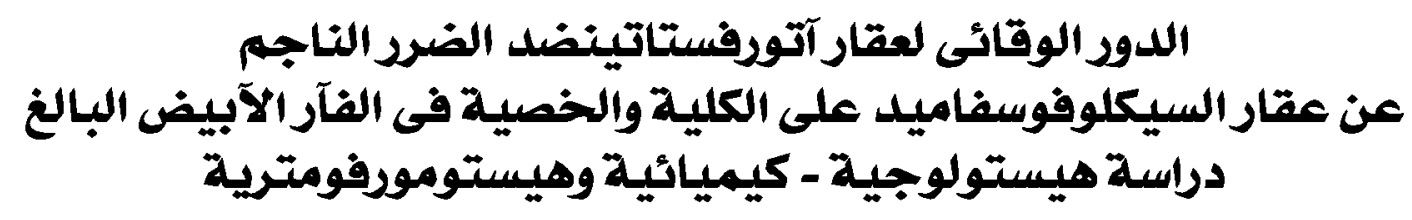

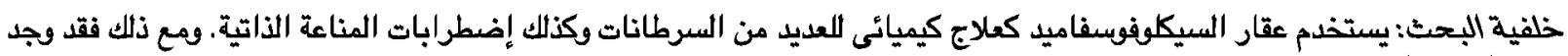

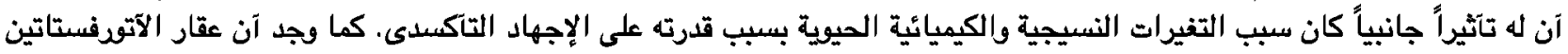
بجرعة منخفضة له خصائص مضادة للاكسدة ومضادة للإلإلتهابات.

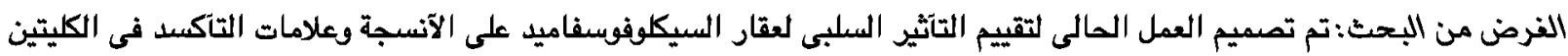
والخصيتين فى ذكود الجرذان اليضاء. علاوة على ذلك قيمت الدراسة دود الآتوفستاتين فى الوقاية والعلاج من التغيرات النسيجية التئية والكيميائية الحيوية الكلوية والخصيتية التى لئى يسبيها.

مواد البحث والطرق المستخدمة: آجريت هذه الدراسة على آريع وعشرون من الفئران البيضاء الذكود البالغة، ستة فئران لكل مجموعة:

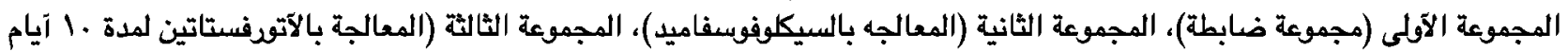

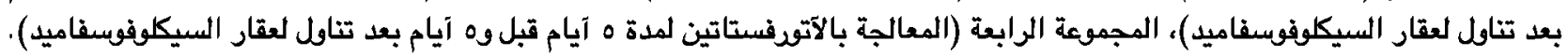

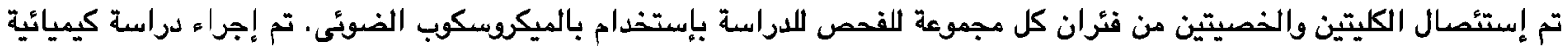
وهيستوموفومترية.

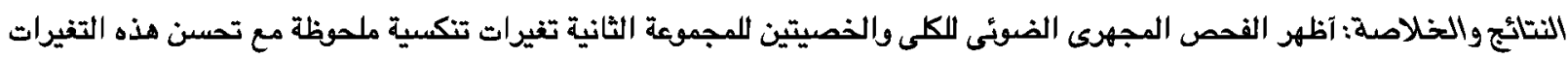

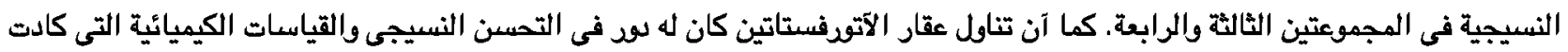

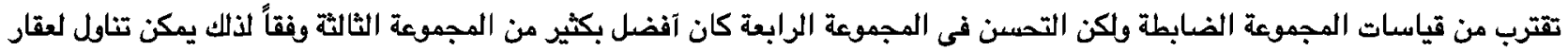
الآتوفستاتين قبل تناول عقار السيكوفوسيفاميد اللحد من آثاره الجانبية على الآنسجة. 